\title{
Effects of intraspecific competition on the life cycle of the stonefly, Nemurella pictetii (Plecoptera: Nemouridae) Reimo Lieske* and Peter Zwick
}

\author{
Address: Limnologische Fluss-Station des Max-Planck-Instituts für Limnologie, Schlitz, Germany \\ Email: Reimo Lieske* - research@berula.de; Peter Zwick - pleco-p.zwick@t-online.de \\ * Corresponding author
}

Published: 16 April 2008

BMC Ecology 2008, 8:5 doi:10.1 / 86/ /472-6785-8-5

This article is available from: http://www.biomedcentral.com/l472-6785/8/5

(C) 2008 Lieske and Zwick; licensee BioMed Central Ltd.

This is an Open Access article distributed under the terms of the Creative Commons Attribution License (http://creativecommons.org/licenses/by/2.0), which permits unrestricted use, distribution, and reproduction in any medium, provided the original work is properly cited.
Received: 10 August 2007

Accepted: 16 April 2008

\begin{abstract}
Background: Considerable variation of life cycle duration in given insect species has been frequently recorded. Splitting of populations into cohorts with different life cycle lengths may occur, sometimes even between siblings from the same batch. Larval populations of the stonefly Nemurella pictetii in central Europe regularly split into a very fast developing and a normal univoltine cohort, leading to partial multivoltinism. The causes for such variation remain unknown but presumably act on the larval stage in which most of the life cycle is spent. We therefore studied possible effects of intraspecific competition on growth and development of larvae in the laboratory.

Results: Intraspecific competition had important influence on growth and development of the larvae. High larval densities led to reduced growth and retarded development through interference, not through exploitative competition. All specimens were negatively affected by frequent encounters and the resulting disturbance. There were no dominant individuals able to grow and develop faster than the rest, at the expense of the others.

Conclusion: Differences in life cycle length of Nemurella pictetii may result from different larval densities in different microhabitats and resultant different degrees of interference competition. Although competition alone probably does not cause splitting of populations into cohorts with different life cycle duration differences in size and development caused by other factors are certainly enhanced by intraspecific competition.
\end{abstract}

\section{Background}

Flexible life cycle duration is widespread in insects [1,2], also among aquatic species [3]. Variation may concern an important portion of normal life cycle length. It arises mainly from differences in the duration of the larval stage in which most of the life cycle is spent [4]. The main causes for such differences are different temperatures, day length or food in the various habitats of the population (see, for example, the review by [5]).
Differences in life cycle length between individuals of a population at the same site have also repeatedly been reported for aquatic insects [6-10], but the causes are less easily explained. In the case of extended hatching from eggs, early hatching individuals are often assumed to have an advantage in development resulting from the combined effects of temperature and longer growth period [11-13]. Such explanations focus mainly on time as factor. However, what causes a population to split into several cohorts growing and developing at different speed? There are no satisfactory explanations so far. Often, cohort split- 
ting occurs when larval density at the respective site is high (see below). Intraspecific competition may be important in this context as shown, for example, in tadpoles $[14,15]$, water striders [16] and also stoneflies [17]. In the mentioned cases, some individuals grew better than the rest, at the expense of the remaining members of the cohort. Possible causes might be competition for space and access to resources (interference), or some direct competition for food (exploitative competition; after [18]).

To investigate possible causes of these frequently observed phenomena we used the stonefly, Nemurella pictetii Klapálek, 1900, as a model species to check for intraspecific competition as a possible cause of cohort splitting in experiments. Our experiments extended previous studies by testing competition under standardised laboratory conditions, for long periods of time. $N$. pictetii is particularly suitable for such study, for several reasons. In appropriate habitats like springs, seeps, and slow flowing spring runs $N$. pictetii may attain very high larval densities (see Table 1). The species is remarkable for a very flexible semito multivoltine life cycle (see references in [19]). It also exhibits cohort splitting, even between siblings from a single egg mass [20]. Some larvae hatching from eggs in spring attain the last instar within three months, emerging as adults and ovipositing in late summer of the same year. Other siblings from the same egg mass require a full year to complete development and emerge the next spring, together with offspring of their fast developing siblings $[20,21]$. Multimodal adult emergence described in other studies (for example, [22-24]) probably also reflects similar cohort splitting. At northern latitudes, N. pictetii may exhibit semivoltine life cycles [25].

The present study attempts to cast light on these problems and is based on the following hypotheses: (1) intraspecific competition does influence growth and development of N. pictetii; (2) the type of competition involved is interference competition. To test these hypotheses, we first compared the immediate effect of different larval densities on speed of larval growth and development (1). In a second experiment we supplied excess food and indirectly estimated the amount of ingested food by determining the amount of faeces produced per unit time, under different larval densities (2). In doing so we assumed that speed of development is positively related to the amount of food ingested per unit time.

\section{Results}

\section{Speed of growth and maturation experiment}

Larval density distinctly influenced both growth and development of the larvae. Larvae kept at low density grew faster and already after two weeks attained significantly larger HCWs than larvae kept at high density. The size differences between the two treatments increased further as the experiment continued (Table 2, Figure 1).

Differences in development of larvae kept at the two different levels of density are evident from the degree of WPD (Mann-Whitney U-test, $Z=-3.996, \mathrm{P}<0.001$; Figure 2) While all larvae kept at low density possessed wing pads at the end of the experiment, the same was true of only $64 \%$ of the larvae kept at high density.

In contrast, HCWR revealed no significant influence of larval density (Mann-Whitney U-test, $\mathrm{Z}=-0.816, \mathrm{P}=$ 0.414 ). The range between the smallest and largest larva in each experimental unit was similar at the two larval densities (Figure 3).

SR was also not influenced by larval density (Mann-Whitney $U$-test, $Z=-0.934, P=0.350$ ). At the end of the experiment, 94 and $93 \%$, respectively, of the larvae survived at low and high density, respectively.

\section{Food ingestion experiment}

Analysis of AF in the food ingestion experiment yielded significant differences among the four treatments. Larval density as well as sex distinctly influenced the amount of faeces produced by a larva (Table 3 ). Animals kept at high density produced fewer faeces than larvae kept at low density and females more than males. For example, male larvae kept at low density produced three times the amount of faeces produced at high density (Figure 4 ).

During the short term experiment, there was no food shortage. During the experiment, dry weight of the available biofilm decreased on average by only $8 \%$, even at high larval density: from a mean DW of $49 \mathrm{mg}(\mathrm{SD}=3)$ at the

Table I: Larval densities of Nemurella pictetii per $\mathbf{m}^{2}$ in different water bodies.

\begin{tabular}{|c|c|c|c|c|}
\hline River & Density & Remarks & Publication & Publication \\
\hline Spring Ravnkilde & Denmark & $29292(08)$ & Moss; first instar possibly not covered, $\mathrm{n}=10$ & {$[42]$} \\
\hline Broadstone Stream & England & I $323(09)$ & Substrates of all kind, $n=40$ & [55] \\
\hline Tributary to stream Biała Przemsza & Poland & $18365(01)$ & Submerged macrophytes, larvae smaller than I $\mathrm{mm}$ not included, $\mathrm{n}=$ ? & {$[23]$} \\
\hline Stream Vel'ký Javorník & Slovakia & ca. $900(12)$ & Gravel and detritus, $n=2-3$ & [56] \\
\hline
\end{tabular}

Abbreviations: density = maximal larval density (in parentheses, the month when it occurs), $n=$ number of parallel samples. 
Table 2: Results of the repeated measures ANOVA of the head capsule width of larvae of $N$. pictetii in the speed of growth and maturation experiment.

\begin{tabular}{lrrrr}
\hline Source of variation & d.f. & MQ & F & $P$ \\
\hline Larval density & I & 0.364 & 61.988 & $<0.001$ \\
Error (larval density) & 17 & 0.006 & & \\
Time & 3 & 2.010 & 1707.342 & $<0.001$ \\
Larval density $\times$ time & 3 & 0.092 & 78.010 & $<0.001$ \\
Error (time) & 51 & 0.001 & & \\
\hline
\end{tabular}

start to a mean of $45 \mathrm{mg} \mathrm{DW}(\mathrm{SD}=4)$ at the end of the experiment.

\section{Discussion}

The results of the speed of growth and maturation experiment confirm our first hypothesis that intraspecific competition influences growth and development of N. pictetii. Both parameters were distinctly affected by larval density. High densities induced significantly slower growth and retarded development than observed at low densities. There were distinct $(\mathrm{P}<0.001)$ differences in HCW as well as in WPD. However, intraspecific competition was not strong enough to distinctly influence survival rate $(\mathrm{P}=$ 0.350 ), which was over $90 \%$ at both factor levels.

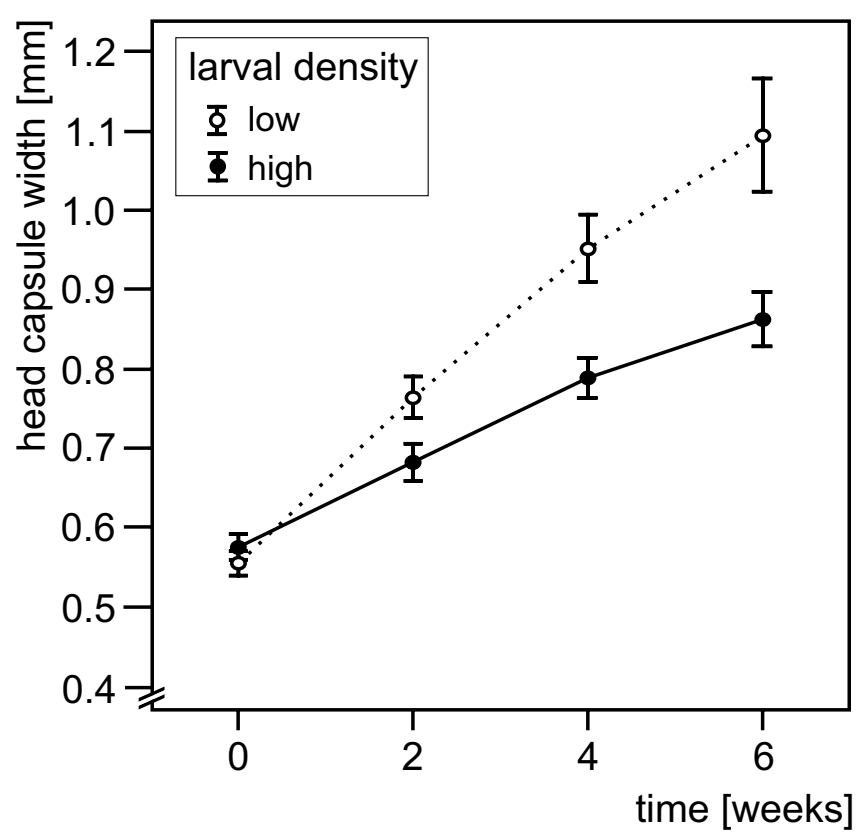

Figure I

Head capsule width of larvae of Nemurella pictetii (mean \pm SD) with time during the speed of growth and maturation experiment. Aggregate values are shown; low larval density (5 larvae per experimental unit): $n$ = 10; high larval density (20 larvae per experimental unit): $n$ $=9$.

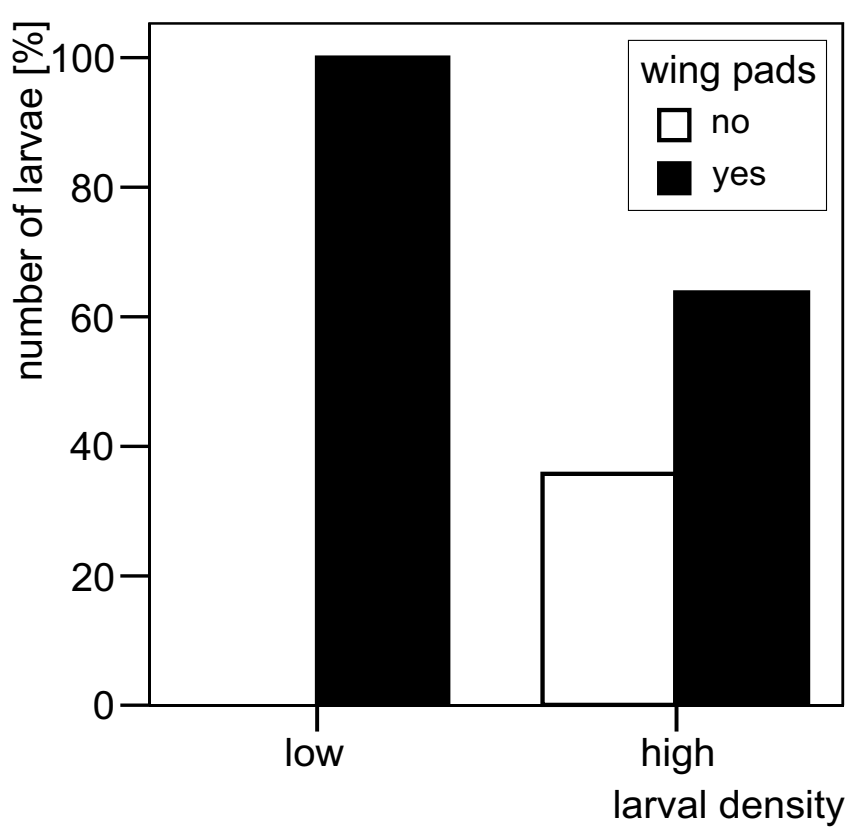

Figure 2

Percentage of larvae of Nemurella pictetii with and without wing pads, respectively, at the end of the speed of growth and maturation experiment.

During preliminary tests we had noticed a striking aggressiveness of larvae during encounters, at least at high densities. Larvae stood head to head, threatening with open mandibles. Actually, antennae but also cerci were often bitten off. Larvae behaved in ways similar to Baetisr hodani (Ephemeroptera) at high larval densities [26]. This author described larvae frequently pushed against others laterally, and conducted abrupt beats with the cerci against the competitor. Each larva may have a critical distance at which no others are tolerated, as described for other aquatic insect larvae with territorial behaviour (Plecoptera: [27], Odonata: [28]). For example, large nymphs of Coenagrion resolutum (Odonata) excluded smaller nymphs from areas with high food resources [28]. The favourable food supply might accelerate development of such larvae over others, and eventually lead to cohort splitting. However, analysis of HCWR suggests no similar mechanisms act in the present case. HCWR was only little wider at high than at low larval densities $(P=0.414)$. At the end of the

Table 3: Results of the ANOVA of the amount of faeces produced by larvae in the food ingestion experiment.

\begin{tabular}{lrrrr}
\hline Source of variation & d.f. & MQ & $F$ & $P$ \\
\hline Larval density & I & 3.376 & 90.584 & $<0.001$ \\
Sex & I & 0.521 & 13.988 & 0.001 \\
Larval density $\times$ sex & I & 0.133 & 3.569 & 0.068 \\
Error & 31 & 0.037 & & \\
\hline
\end{tabular}




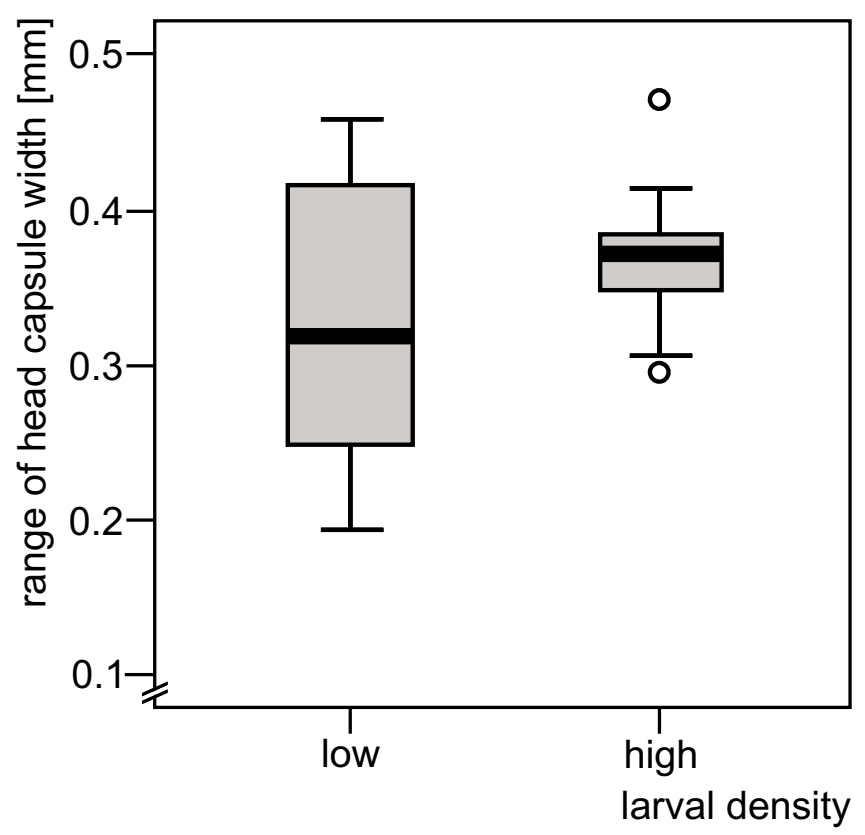

Figure 3

Range of head capsule width of larvae of Nemurella pictetii per experimental unit at the end of the speed of growth and maturation experiment. Low larval density ( 5 larvae per experimental unit): $n=10$; high larval density (20 larvae per experimental unit): $n=9$; in the boxplot, the box represents the interquartile range divided at the median; vertical lines indicate minimum and maximum values, circles identify outliers (i.e. I.5-3 box lengths from the edges of the box).

experiment, there were no individuals in a unit that were strikingly larger than the rest; drastic suppression of some of the larvae by a few others appears improbable. The fact that HCWR of larvae was similar at both factor levels while HCW and WPD differed distinctly suggests two other causes.

First, N. pictetii larvae are very active and move around frequently $[19,29,30]$. At high larval density, disturbance during frequent encounters of larvae may retard development which would be interference competition. Stress during frequent encounters is supposed to reduce food ingestion and further increase locomotion. Hence, metabolic cost would increase at the expense of resources for growth. Our second consideration concerns exploitative competition. Shortage of high quality food (for example, densely microbially colonised leaf patches) may have caused retarded development at high larval density, affecting all individuals in a similar way.

The food ingestion experiment elucidated the kind of intraspecific competition more precisely. The distinctly negative correlation $(\mathrm{P}<0.001)$ between larval density

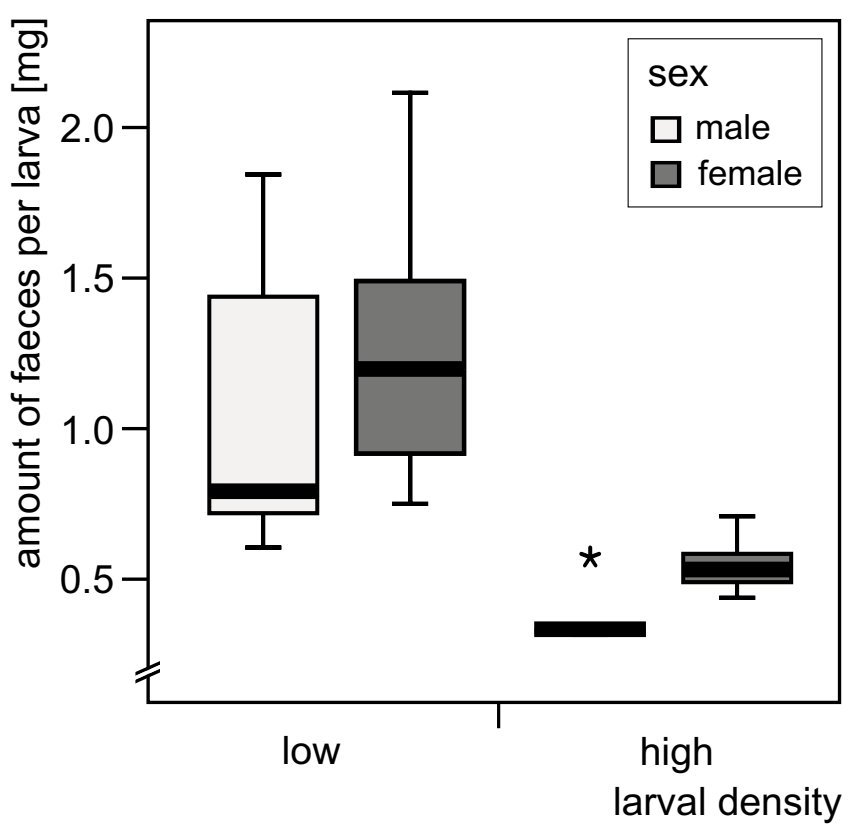

Figure 4

Amount of faeces produced by individual Nemurella pictetii larvae (final three instars) during 66 hours when kept at low and at high larval density, respectively. Low larval density (I larva per experimental unit): $\mathrm{n}=$ 7 (males), $n=14$ (females); high larval density (5 larvae per experimental unit): $n=5$ (males), $n=9$ (females); the star identifies an extreme value (more than 3 box lengths from the edges of the box), for further explanations of symbols see Figure 3.

and amount of faeces produced by a larva does not suggest exploitative competition, for several reasons. On the one hand, biofilm is a high quality resource [31,32] that N. pictetii prefers [19]. On the other hand, enough biofilm remained during our short term experiments to exclude food shortage. Larvae used in the experiment were of comparable size and similarly far developed. Also, the biofilm used offered uniform food quality across the entire feeding plot. Therefore, interference (competition for space) seems to have been decisive, which supports our second hypothesis. Frequent encounters seem to have hindered ingestion of food. A recent study [30] found comparable evidence. Among other, the authors studied mass loss of conditioned alder leaves in relation to larval density of $N$. pictetii and also found a negative correlation. Like ourselves, they attributed their results to the high activity of the species and also regarded interference as cause of the correlation. In contrast, studies of intraspecific competition among slowly moving grazers like Trichoptera $[33,34]$ or Gastropoda [35] regarded exploitative competition as more important factor than interference. 
Although intraspecific competition importantly influences the life cycle length of $N$. pictetii it can hardly by itself cause the cohort splitting observed both in the field and in the laboratory. Egg development of N. pictetii is direct and synchronous, egg rests that are important in other stoneflies [36-38] do not occur in the present species ([20], own investigations). Instead, several factors may act in combination. Possibly, intraspecific competition resulting from high larval densities drives part of the population into suboptimal microhabitats with reduced availability of high quality food, i.e., benthic algae [19] where detritus or the like must instead be consumed. MACAN'S [39] reasoning to explain why the development of Pyrrhosoma nymphula (Odonata) takes 2 years in some microhabitats but 3 years in others is similar (compare $[40,41])$.

\section{Conclusion}

In conclusion, intraspecific competition may importantly influence length of larval life and consequently the entire life cycle of the present species. Given the high larval densities of over 29000 specimens per square meter ([42]; see Table 1) observed in some habitats, interference competition must decisively influence the life cycle.

In our experiments, we observed interference competition, but no animal was able to profit at the expense of others. Therefore, cohort splitting observed in the field $[20,21]$ cannot be explained by direct competition, provided the animals inhabit restricted areas with similar food quality. However, in more heterogeneous habitats displacement of some specimens to less favourable sites with lower food quality (e.g., detritus) can be conceived, especially in view of the aggressive behaviour observed in the present species. Size differences caused by different food qualities [19] may thus be enhanced through intraspecific competition by increasing territorial behaviour, as shown in water striders $[16,43]$. Further study is needed for a precise analysis of the situation.

\section{Methods \\ Study organism}

Larvae examined for speed of growth and development (experiment 1) came from the spring of the first order stream Breitenbach $\left(50^{\circ} 40^{\prime} \mathrm{N}, 9^{\circ} 38^{\prime} \mathrm{E}, 280 \mathrm{~m}\right.$, see $[44,45])$. Size of specimens at the start of the experiment is given in Figure 1.

Larvae tested for food ingestion (experiment 2) were collected in the spring of the River Fulda $\left(50^{\circ} 30^{\prime} \mathrm{N}, 09^{\circ} 56^{\prime} \mathrm{E}\right.$, $850 \mathrm{~m}$, see [21]). The specimens were in the last three larval instars and were kept without food for 1 1/2 days before the experiment.

\section{Rearing condition}

\section{Rearing Systems and Experimental Units}

The flowing water system used in the experiment on speed of growth and maturation consisted of a reservoir (25 l) from which an aquarium filter pump (Eheim, Typ 1026; $11.81 \mathrm{~min}^{-1}$, Deizisau, Germany) pumped water into plastic tubes $(\varnothing=15 \mathrm{~mm})$ with boreholes at regular distances. Each resulting water jet entered an experimental unit (poly-propylene, base area $=4.5 \times 4.5 \mathrm{~cm}$, volume $=70$ $\mathrm{ml}$ ) through a screen window (mesh size $=80 \mu \mathrm{m}$ ) in the lid. Water left via similar screen windows in the sides of the unit, flowing back to the reservoir via a trough. For details and illustrations, see [46] and [47].

A different flowing water system circulating a larger volume of water was used in the food ingestion experiment (for details see [19]). Each experimental unit consisted of two conical plastic beakers (poly-propylene, basal $\varnothing=5.5$ $\mathrm{cm}$, volume $=170 \mathrm{ml}$ ) of which one had a gauze bottom (mesh size $=1500 \mu \mathrm{m})$ and was placed into the other beaker.

We used water from the Breitenbach in both experiments; for notes on its chemical properties see [48]. In the long lasting speed of growth and maturation experiment about half the water was replaced once a week. Random water samples revealed no change of water quality (conductivity, ammonium, nitrate and phosphate) during the experiments. Water temperature was $12^{\circ} \mathrm{C}$, daylength was $16 \mathrm{~h}$ light: $8 \mathrm{~h}$ dark in both experiments. Water temperature was recorded with a datalogger (1250 series, Grant Instruments [Cambridge] Ltd., Cambridgeshire, UK) at 10-min intervals.

\section{Food}

In the speed of growth and maturation experiment we used chips (area $\approx 11 \mathrm{~cm}^{2}$ ) from soft alder (Alnus glutinosa) shade leaves that had fallen in autumn. Air dried leaves were soaked in water for half a day, the chips punched with a metal tube and conditioned in aerated Breitenbach water for 2 weeks in the dark at 12 to $14^{\circ} \mathrm{C}$ before they were used as food. One leaf chip was randomly assigned to each experimental unit. Food was replaced twice a week.

In the food ingestion experiment we used unglazed clay tiles $(5 \times 5 \times 0.5 \mathrm{~cm}$; for details see [19]) after they had been exposed in trays in the Breitenbach for establishment of a natural biofilm [49]. This type of food resource has several advantages. It is the preferred food of N. pictetii [19], biofilm quantity and quality tend to be uniform across the entire area of a tile [50], and faeces fell directly through the gauze bottom into the lower collecting beaker when tiles were placed obliquely into the experimental units, with the biofilm on the lower side. 


\section{Experimental procedure and variables measured}

The speed of growth and maturation experiment lasted for 44 days. Two factor levels (low and high larval density) were tested. Experiments started with 5 and 20 larvae, respectively, per experimental unit corresponding to 2500 and 9900, respectively, individuals $/ \mathrm{m}^{2}$ stream bottom. We used 10 and 9 experimental units, respectively, for experiments at low and high density, respectively. The increase in head capsule width across the eyes (HCW) during the experiment was recorded to document possible differences in growth and development between the treatments. HCW was measured four times: before the experiment, and then every second week using a dissecting microscope (WILD M5, Wild, Heerbrugg, Switzerland) combined with a digitizing tablet (Numonics 2200, Numonics, Montgomeryville, Pennsylvania, U.S.A). At the end of the experiment, we additionally recorded the range of HCWs in each experimental unit (HCWR), the number of individuals with wing pads as a measure of degree of maturation (WPD, wing pad development), and the survival rate (SR, percentage of larvae surviving since the start of the experiment). SR was calculated separately for each experimental unit, we here present the mean across all units. Since individual larvae could not be marked and identified, HCW and WPD were aggregated at the level of experimental units by calculating means per unit.

Two factor levels (low and high larval density, 1 and 5 larvae per unit, respectively, corresponding to 400 and 2100 individuals $/ \mathrm{m}^{2}$ stream bottom) were also tested in the food ingestion experiment. Lower numbers of larvae than in the previous experiment were used because the present larvae were much larger $($ mean $\mathrm{HCW}=1.21 \mathrm{~mm}, \mathrm{SD}=$ 0.09). We assessed the amount of ingested food indirectly by recording the amount of faeces produced (AF), on the assumption that larvae frequently disturbed by competitors would feed and defecate less. However, it was impossible to document the degree of disturbance precisely by counting the number of aggressive encounters between larvae during the experiment. The experiment lasted for 66 hours. Gut passage times in N. pictetii are only one to two hours [51], sufficiently many faecal pellets [52] were therefore produced during the experiment. $N$. pictetii grazes very efficiently on the biofilm, all detached pieces of biofilm are actually also eaten (personal observations). Therefore, only faeces dropped into the lower beaker of each experimental unit. A manual vacuum pump (MityvacII, Nalgene, Rochester, U.S.A.) was used to transfer the accumulated faeces to glass fibre microfilters $(\mathrm{GF} / \mathrm{C}, \varnothing=$ $25 \mathrm{~mm}$, Whatman plc, Brentford, England). The filters were placed into small aluminium cups and dried at $105^{\circ} \mathrm{C}$ for 72 hrs (drying oven T6060, Heraeus, Hanau, Germany). Samples were allowed to cool in an exsiccator for three hours and were then weighed with an ultra microscale (4504 MP8, Sartorius, Göttingen, Germany). Before use, cups and filters had been in a furnace at $500^{\circ} \mathrm{C}$ for 2 hrs and were pre-weighed as described above. The amount of faeces produced during the experiment was the difference between the two readings.

Sexual dimorphism of $N$. pictetii is pronounced towards the end of the larval period [21,53]. Therefore, sex was included in the experimental design as an additional factor by running replicates separately for each sex. This as well as the use of only the last three larval instars was also intended to exclude that some individuals were much larger than the others, and might become dominant and possibly territorial. Shortly before molts, stonefly larvae do not feed (see references in [54]). To exclude any possible error caused by this we analysed only replicates in which no molts had occurred during the experiment. Seven experimental units with males and 14 with females were analysed at low density, and 5 and 9, respectively, at high density. Except for sex in the second experiment, larvae were randomly assigned to experimental units.

\section{Statistical analyses}

We performed a repeated measures ANOVA to test for possible differences of HCW in the speed of growth and maturation experiment. Because variances within samples were not homogenous (Levene-Test), data were transformed (transformation exponent: -1). Differences in WPD, SR and HCWR were assessed with Mann-Whitney U-tests.

Possible differences in AF in the food ingestion experiment were also assessed with an ANOVA. Data were transformed (transformation exponent $=-0.584$ ) for the same reason as before.

\section{Abbreviations}

AF: amount of faeces; HCW: head capsule width across the eyes; HCWR: range of head capsule width of larvae in single experimental units; SR: survival rate; WPD: wing pad development.

\section{Authors' contributions}

The study was jointly planned by RL and PZ. RL performed the experiments and the statistical analyses. RL and PZ together wrote the present manuscript.

\section{Acknowledgements}

We would like to thank Friederike Weinreich, Lena Schlag and Mirjam Appel for technical help in the laboratory. We are grateful to I.D. McLellan (Westport, N.Z.) for checking and correcting our English. Two anonymous referees helped to improve our paper.

\section{References}

I. Danks HV: Life cycle pathways and the analysis of complex life cycles in insects. Can Entomol 1991, I 23(1):23-40. 
2. Danks HV: Diversity and integration of life-cycle controls in insects. In Insect life-cycle polymorphism: Theory, evolution and ecological consequences for seasonality and diapause control Volume 52. Edited by: Danks HV. Dordrecht, Kluwer Academic Publishers; 1994:5-40.

3. Butler MG: Life histories of aquatic insects. In The ecology of aquatic insects Edited by: Resh VH, Rosenberg DM. New York, Praeger Publishers; 1984:24-55

4. Zissler D: Entwicklung. In Lehrbuch der Entomologie 2nd edition. Edited by: Dettner K, Peters W. Heidelberg, Spektrum Akademischer Verlag; 2003:395-420.

5. Sweeney BW: Factors influencing life-history patterns of aquatic insects. In The ecology of aquatic insects Edited by: Resh VH, Rosenberg DM. New York, Praeger Publishers; 1984:56-100.

6. Iversen TM: Life cycle and growth of Trichoptera in a Danish spring. Arch Hydrobiol 1976, 78(4):482-493.

7. Pritchard G: Life budgets for a population of Tipula sacra (Diptera, Tipulidae). Ecol Entomol 1980, 5(2): |65-173.

8. Heise BA, Flannagan JF, Galloway TD: Life histories of Hexagenia limbata and Ephemera simulans (Ephemeroptera) in Dauphin Lake, Manitoba. I North Am Benthol Soc 1987, 6(4):230-240.

9. Aoki T: Larval development, emergence and seasonal regulation in Asiagomphus pryeri (Selys) (Odonata: Gomphidae). Hydrobiologia 1999, 394:179-192.

10. Schultheis AS, Hendricks AC, Weigt LA: Genetic evidence for 'leaky' cohorts in the semivoltine stonefly Peltoperla tarteri (Plecoptera: Peltoperlidae). Freshw Biol 2002, 47(3):367-376.

II. Moreira GRP, Peckarsky BL: Multiple developmental pathways of Agnetina capitata (Plecoptera: Perlidae) in a temperate forest stream. J North Am Benthol Soc 1993, I3(I): 19-29.

12. Townsend GD, Pritchard G: Larval growth and development of the stonefly Pteronarcys californica (Insecta: Plecoptera) in the Crowsnest River, Alberta. Can J Zool 1998 76(1 2):2274-2280.

13. Ferreras-Romero M, Atienzar MD, Corbet PS: The life cycle of Onychogomphus uncatus (Charpentier, I840) (Odonata: Gomphidae) in the Sierra Morena Mountains (southern Spain): An example of protracted larval development in the Mediterranean basin. Arch Hydrobiol 1999, I44(2):215-228.

14. Wilbur HM: Density dependent aspects of growth and metamorphosis in Bufo americanus. Ecology I977, 58(I): 196-200.

15. Wilbur HM: Density-dependant aspects of metamorphosis in Ambystoma and Rana sylvatica. Ecology 1976, 57(6): | 289-1296.

16. Blanckenhorn WU: Divergent juvenile growth and development mediated by food limitation and foraging in the water strider Aquarius remigis (Heteroptera: Gerridae). I Zool (Lond) 2006, 268(I): I7-23.

17. Peckarsky BL, Cowan CA: Consequences of larval intraspecific competition to stonefly growth and fecundity. Oecologia (Berl) |99|, 88(2):277-288.

18. Schoener TW: Field experiments on interspecific competition. Am Nat 1983, I 22(2):240-285

19. Lieske R, Zwick P: Food preference, growth and maturation of Nemurella pictetii (Plecoptera: Nemouridae). Freshw Biol 2007, 52(7): I| $187-1 \mid 97$

20. Wolf $B$, Zwick P: Plurimodal emergence and plurivoltinism of Central European populations of Nemurella pictetii (Plecoptera: Nemouridae). Oecologia (Berl) 1989, 79(4):431-438.

21. Nesterovitch A, Zwick P: The development of Nemurella pictetii Klapálek (Plecoptera: Nemouridae) in two springstreams in central Europe. Limnologica 2003, 33(4):23 I-243.

22. Lavandier $P$, Dumas J: Cycles de développment de quelques invertébrés benthiques dans de Ruisseaux des Pyrénées Centrales. Ann Limnol I97I, 7(2): I57-I72.

23. Fialkowski W: Life cycles and microdistribution of Nemoura cinerea (Retz.) and Nemurella picteti Klap. (Plecoptera Nemouridae) from two small lowland streams in Southern Poland. Acta Hydrobiologica 1986, 28( I-2): 199-2। 3.

24. Petersen I, Winterbottom JH, Orton S, Friberg N, Hildrew AG, Spiers DC, Gurney WSC: Emergence and lateral dispersal of adult Plecoptera and Trichoptera from Broadstone Stream, U.K. Freshw Biol 1999, 42(3):401-416.

25. Brittain JE: Semivoltinism in mountain populations of Nemurella pictetii (Plecoptera). Oikos 1978, 30(I): I-6.

26. Bohle HW: Beziehungen zwischen dem Nahrungsangebot, der Drift und der räumlichen Verteilung bei Larven von Bae- tis rhodani (Picket) (Ephemeroptera: Baetidae). Arch Hydrobiol 1978, 84(4):500-525.

27. Sjöström P: Territoriality in nymphs of Dinocras cephalotes (Plecoptera). Oikos 1985, 45(3):353-357.

28. Baker RL: Use of space in relation to feeding areas by zygopteran nymphs in captivity. Can J Zool 1980, 58(6): I060-1065.

29. Winterbottom JH, Orton SE, Hildrew AG: Field experiments on the mobility of benthic invertebrates in a southern English stream. Freshw Biol I997, 38( I):37-47.

30. Jonsson $M$, Malmqvist $B$ : Mechanisms behind positive diversity effects on ecosystem functioning: Testing the facilitation and interference hypotheses. Oecologia (Berl) 2003, I34(4):554-559.

31. Anderson $\mathrm{NH}$, Cummins $\mathrm{KW}$ : Influences of diet on the life histories of aquatic insects. J Fish Res Board Can 1979, 36(3):335-342.

32. Cummins KW, Klug MJ: Feeding ecology of stream invertebrates. Annu Rev Ecol Syst 1979, I0:147-172.

33. Hart DD: Experimental studies of exploitative competition in a grazing stream insect. Oecologia (Berl) 1987,73 (I):4I-47.

34. Lamberti GA, Feminella JW, Resh VH: Herbivory and intraspecific competition in a stream caddisfly population. Oecologia (Berl) 1987, 73(I):75-81.

35. Cross WF, Benke AC: Intra- and interspecific competition among coexisting lotic snails. Oikos 2002, 96(2):25I-264.

36. Zwick P: Variable egg development of Dinocras spp (Plecoptera, Perlidae) and the stonefly seed bank theory. Freshw Biol 1996, 35(I):81-99.

37. Zwick P: The stonefly (Insecta: Plecoptera) seed bank theory: new experimental data. Verhandlungen der Internationalen Vereinigung für Theoretische und Angewandte Limnologie 2003, 28(3): $|3| 7-1323$

38. Marten $M$, Zwick $P$ : The temperature dependence of embryonic and larval development in Protonemura intricata (Plecoptera: Nemouridae). Freshw Biol 1989, 22: I-I4.

39. Macan TT: The Odonata of a moorland fishpond. Internationale Revue der gesamten Hydrobiologie 1964, 49:325-360.

40. Norling U: The life cycle and larval photoperiodic responses of Coenagrion hastulatum (Carpentier) in two climatically different areas (Zygoptera: Coenagrionidae). Odonatologica I 984, I3(3):429-449.

4I. Johansson F, Norling U: A five year study of the larval life history of Coenagrion hastulatum (Charpentier) ans C. armatum (Charpentier) in northern Sweden (Zygoptera: Coenagrionidae). Odonatologica 1994, 23(4):355-364

42. Lindegaard C, Thorup J: The invertebrate fauna of the moss carpet in the Danish spring Ravnkilde and its seasonal, vertical, and horizontal distribution. Arch Hydrobiol 1975, 75(I): I09-I39.

43. Wilcox RS, Ruckdeschel T: Food threshold territoriality in a water strider (Gerris remigis). Behav Ecol Sociobiol 1982 I I (2):85-90.

44. Cox EJ: Studies on the algae of a small softwater stream I. Occurrence and distribution with particular reference to the diatoms. Arch Hydrobiol Suppl 1990, 83(4):525-552.

45. Wagner R, Schmidt HH, Marxsen J: The hyporheic habitat of the Breitenbach, spatial structure and physicochemical conditions as a basis for benthic life. Limnologica 1993, 23(4):285-294.

46. Zwick P, Teslenko VA: Development and life history of far eastern Russian Pteronarcys spp. (Plecoptera, Pteronarcyidae). Arch Hydrobiol 2002, I 53(3):503-528.

47. Zwick P, Hohmann M: Direct development, no diapause, in Taeniopteryx nebulosa (Plecoptera, Taeniopterygidae). Lauterbornia 2003, 47:|4|-|5|.

48. Marxsen J, Schmidt HH, Fiebig DM: Organic matter dynamics in the Breitenbach, Germany. J North Am Benthol Soc 1997, I 6( I):28-32.

49. Becker G, Holfeld H, Hasselrot AT, Fiebig DM, Menzler DA: Use of a microscope photometer to analyze in vivo fluorescence intensity of epilithic microalgae grown on artificial substrata. Appl Environ Microbiol 1997, 63(4): $1318-1325$.

50. Lamberti GA, Resh VH: Comparability of introduced tiles and natural substrates for sampling lotic bacteria, algae and macroinvertebrates. Freshw Biol 1985, I 5(I):2I-30.

51. Henderson J, Hildrew AG, Townsend CR: Detritivorous stoneflies of an iron-rich stream: Food and feeding. In Mayflies and Stoneflies Edited by: Campbell IC. Dordrecht, Kluwer Academic Publishers; 1990:249-254. 
52. Winterbourn MJ, Hildrew AG, Box A: Structure and grazing of stone surface organic layers in some acid streams of southern England. Freshw Biol 1985, 15(3):363-374.

53. Zwick P: Biometric studies of the growth and development of two species of Leuctra and of Nemurella pictetii (Plecoptera: Leuctridae and Nemouridae). In Overview and Strategies of Ephemeroptera and Plecoptera Edited by: Alba-Tercedor J, SanchezOrtega A. Gainesville, Sandhill Crane Press; 1991:515-526.

54. Zwick P: 7. Plecoptera (Steinfliegen). In Handbuch der Zoologie, Band 4: Arthropoda - 2 Hälfte: Insecta, 2 Teil: Spezielles Edited by: Helmcke JG, Starck D, Wermuth H. Berlin, Walter de Gruyter; 1980:I-II5.

55. Hildrew AG, Townsend CR: Predators and prey in a patchy environment: A freshwater study. J Anim Ecol 1982, $5 I(3): 797-8 I 5$.

56. Krno I: Influence of abiotic and biotic factors on the life cycles and production of stoneflies (Plecoptera) in an acidified spring area. Biologia (Bratisl) 1998, 53(2): 195-204.

Publish with Biomed Central and every scientist can read your work free of charge

"BioMed Central will be the most significant development for disseminating the results of biomedical research in our lifetime. "

Sir Paul Nurse, Cancer Research UK

Your research papers will be:

- available free of charge to the entire biomedical community

- peer reviewed and published immediately upon acceptance

- cited in PubMed and archived on PubMed Central

- yours - you keep the copyright

Submit your manuscript here:

http://www.biomedcentral.com/info/publishing_adv.asp 